mention the menopause as a supposed cause of depression in middle age before dismissing it as of very little importance.

What, then, of the psychosocial explanations? For doctors this will be less familiar territory, though much in the news in the last few years. Can some of the excess of depression in women arise from an alleged disadvantaged social status or from a confusion of roles? Are women in Western societies trained to be dependent and helpless and to expect little? Various authors have found-and this may come as a surprise -that rates for several varieties of mental illness are higher in married women than in single, divorced, and widowed women. Marriage appears to protect men from depression but has a detrimental effect on women. Weissman and Klerman discuss explanations for the high rates in women in terms both of psychoanalytic theory of female psychological development and of the psychodynamic theory of the psychogenesis of depression.

Despite the huge number of documents surveyed by these two American authors they come to no firm conclusions about the relative importance of genetic, endocrine, or psychosocial causes. They plead for comprehensive research, a hope that Dr John Pollitt, the author of the second study, ${ }^{2}$ would certainly echo. His presidential address to the section of psychiatry of the Royal Society of Medicine, delivered nearly a year ago and only partly reported in the Proceedings, covered much the same ground. He noted that the most vulnerable time for women is from puberty to the age of 45 and that after 55 the sex rates for depression are equal. He was impressed by Dalton's finding ${ }^{5}$ that $60 \%$ of depressed women who were admitted to hospital were admitted on 12 days of the month (around ovulation, premenstrually, and during menstruation) and only $40 \%$ on the remaining 16 days. Suicide attempts are rather similarly concentrated.

Pollitt found the studies of heredity and cultural influences disappointing. He thinks endocrine explanations for the inequality in the rates of depression are much more convincing than psychosocial ones. If he is right neither the Sex Discrimination Act nor any other piece of legislation is likely to alter this depressing fact of life.

1 Weissman, M M, and Klerman, G L, Archives of General Psychiatry, $1977,34,854$.

2 Pollitt, J, Proceedings of the Royal Society of Medicine, 1977, 70, 145.

${ }^{3}$ Holmes, T H, and Rahe, R H, fournal of Psychosomatic Research, 1967, 11, 213.

${ }^{4}$ Paykel, E S, Prusoff, B A, and Uhlenhuth, E H, Archives of General Psychiatry, 1971, 25, 340.

${ }^{5}$ Dalton, K, The Premenstrual Syndrome. London, Heinemann, 1964.

\section{Viruses and cardiomyopathy}

\begin{abstract}
Almost any virus that infects man may affect the heart, though Coxsackie B is the most common culprit. ${ }^{1}$ Infection may occur at any age; maternal rubella infection accounts for about $2 \%$ of cases of congenital heart disease and the Coxsackie virus may possibly do the same. ${ }^{2}$

Proof of virus infection depends either on isolating the organism or finding a rising titre of specific viral antibodies in the blood. Both procedures have problems. The initial stage of viraemia may have passed by the time any cardiac lesion becomes apparent, and the large number of potentially infective viruses means that an exhaustive series of serological tests may be needed to exclude a viral cause for the illness.
\end{abstract}

The neonatal period is a time when the myocardium is particularly susceptible to viral infection. The child may die, when it may be possible to isolate the virus directly from the myocardium. ${ }^{3}$ In adults, clinical clues to viral myocarditis include chest pain, tachycardia disproportionate to the degree of fever, and T-wave changes on the electrocardiogram. Changes in laboratory test results may include a raised sedimentation rate, neutrophil leucocytosis, and modest rise of cardiac enzymes. ${ }^{4}$ None of these changes is specific and, unless a viral origin is suspected and confirmed (for example, by isolation from stools or by a fourfold rise in neutralising antibodies), a young man with these symptoms may be wrongly diagnosed as having ischaemic heart disease. Since the prognosis is usually quite different in the two cases this distinction is important.

Viral myocarditis is probably commoner than generally supposed: in one series a third of patients with proved viral or mycoplasma infections had ST/T-wave changes on their electrocardiograms suggestive of myocarditis ${ }^{5}$ - though these changes are non-specific, and may indeed even be induced by hyperventilation. ${ }^{6} \mathrm{~A}$ similar proportion of 50 consecutive cases studied during a recent influenza A epidemic showed electrocardiographic changes. ${ }^{7}$ Most such examples of myocarditis resolve with no long-term effects, but a few patients may have permanent myocardial damage and develop congestive cardiomyopathy. This possibility was first shown experimentally by Wilson et $a l^{8}$ in 1969; their mice infected with Coxsackie A9 virus developed a transient myocarditis which soon healed, whereas those infected with Coxsackie B3 had a much more florid acute illness and showed permanent myocardial injury. Virus could be isolated from the heart in the acute but not the chronic stage.

These experiments, and those of Kawai, ${ }^{9}$ have provided a possible model for viral cardiomyopathy in man. How relevant are they to human disease? There are two possible approaches to answering that question: cases of proved acute viral myocarditis may be followed up, or patients with cardiomyopathy may be investigated for previous viral infection. Using the first approach, Sainani et al found that five out of 22 patients with Coxsackie myocarditis or pericarditis developed chronic heart failure, while Levi et al ${ }^{10}$ found that three out of 10 patients who had had Coxsackie myocarditis five years previously showed cardiac enlargement on their chest radiograph and prolongation of the ventricular pre-ejection period. Another series from Ceylon ${ }^{11}$ reported that 26 out of 35 patients with arbovirus myocarditis developed persistent enlargement of the heart. The second approach has also provided some hints that viruses may be implicated in a substantial proportion of cases. Kawai ${ }^{9}$ found a higher titre of antibodies to Coxsackie $\mathrm{B}$ and herpes virus in patients with cardiomyopathy than in controls, though another survey by Fletcher et $a l^{12}$ found no difference.

Congestive cardiomyopathy is almost certainly the end result of many different disease processes. Nevertheless, the possibility that some of these cases may occur as a result of viral infections certainly merits further investigation.

\footnotetext{
${ }^{1}$ Smith, W G, British Heart fournal, 1966, 26, 204.

2 Overall, J C, American Heart Fournal, 1972, 84, 823.

3 Woodward, T E, et al, Annals of Internal Medicine, 1960, 53, 1130.

- Sainani, G S, et al, Medicine, 1968, 47, 133.

5 Lewis, D, et al, British Heart fournal, 1974, 36, 924.

${ }^{6}$ Biberman, L, et al, American Heart fournal, 1971, 81, 166

${ }^{7}$ Verel, D, et al, American Heart fournal, 1976, 92, 290.

8 Wilson, F M, et al, American fournal of Pathology, 1969, 55, 253.

- Kawai, C, and Takatsu, T, New England fournal of Medicine, 1975, 293, 592.

${ }^{10}$ Levi, G F, et al, American Heart fournal, 1977, 93, 419.

11 Obeyesekere, I, and Hermon, Y, American Heart fournal, 1973, 85, 186.

12 Fletcher, G F, et al, American fournal of Cardiology, 1968, 21, 6.
} 